\title{
OPEN Author Correction: The tomato subtilase family includes several cell death-related proteinases with caspase specificity
}

\author{
Sven Reichardt, Dagmar Repper, Alexander I. Tuzhikov, Raisa A. Galiullina, Marc Planas- \\ Marquès, Nina V. Chichkova, Andrey B. Vartapetian, Annick Stintzi $₫$ \& Andreas Schaller $\mathbb{B}$
}

Correction to: Scientific Reports https://doi.org/10.1038/s41598-018-28769-0, published online 12 July 2018

This Article contains an error in the Methods section under subheading 'Substrate specificity of tomato phytaspases' where,

"Briefly, a protein extract from Arabidopsis leaves was digested with proteomics-grade trypsin to generate a library of several thousand peptides, that were chemically modified to protect free sulfhydryl and amino groups."

should read:

"Briefly, a protein extract from Arabidopsis leaves was digested with proteomics-grade chymotrypsin to generate a library of several thousand peptides, that were chemically modified to protect free sulfhydryl and amino groups."

In addition, there is an error in the legend of Figure 4 where,

"Letter size reflects the relative frequency of an amino acid at a given position as compared to natural abundance in the tomato proteome."

should read:

"Letter size reflects the relative frequency of an amino acid at a given position as compared to natural abundance in the Arabidopsis proteome."

(c) (i) Open Access This article is licensed under a Creative Commons Attribution 4.0 International cc. License, which permits use, sharing, adaptation, distribution and reproduction in any medium or format, as long as you give appropriate credit to the original author(s) and the source, provide a link to the Creative Commons license, and indicate if changes were made. The images or other third party material in this article are included in the article's Creative Commons license, unless indicated otherwise in a credit line to the material. If material is not included in the article's Creative Commons license and your intended use is not permitted by statutory regulation or exceeds the permitted use, you will need to obtain permission directly from the copyright holder. To view a copy of this license, visit http://creativecommons.org/licenses/by/4.0/.

(C) The Author(s) 2020 